\title{
The role of classroom management and mastery goal orientation towards student's self-regulation in learning Mathematics
}

\author{
Berliana Henu Cahyani, ${ }^{1}$ Asmadi Alsa, ${ }^{2 *}$ Neila Ramdhani, ${ }^{3}$ Fakher Nabeel Khalili ${ }^{4}$ \\ ${ }^{1}$ Faculty of Psychology, Universitas Sarjanawiyata Tamansiswa, Yogyakarta - Indonesia, ${ }^{2}$ Faculty of Psychology, \\ Universitas Persada Indonesia YAl, Jakarta - Indonesia, ${ }^{3}$ Faculty of Psychology, Universitas Gadjah Mada, \\ Yogyakarta - Indonesia, ${ }^{4}$ Departement of Psychology and Counseling, Faculty of Education, An-Najah National \\ University, Nablus - Palestine
}

\begin{abstract}
Mathematics until today is still considered a difficult subject so that it needs to think about appropriate strategies to encourage students to be able to regulate themselves in learning this subject. This study aimed to test empirically the role of classroom management and mastery goal orientation towards self-regulated learning. The participants of the study were 177 students of state high schools in Sleman, who were selected using a purposive sampling technique. The scales used were self-regulation of Mathematics learning scale, classroom management scale, and mastery goal orientation scale. The data analysis using two-predictor regression analysis showed that classroom management and mastery goal simultaneously played a significant role by $68.7 \%(R 2=0.687, \mathrm{~F}(2.177)=191.243, \mathrm{p}<0.01)$. Classroom management predicted self-regulation $(\beta=-0.130, \mathrm{p}<0.01)$, and so did mastery goal $(\beta=0.878, p<0.01)$. Based on the results of this study, it could be concluded that selfregulation in learning Mathematics can be determined through classroom management and mastery goals concurrently.
\end{abstract}

Keywords: mastery goal orientation; classroom management; self-regulation; learning Mathematics

\begin{abstract}
Abstrak: Matematika sampai saat ini dipandang sebagai pelajaran yang sulit, oleh karena itu perlu dipikirkan strategi yang tepat untuk menggairahkan siswa agar dapat meregulasi diri dalam belajar Matematika. Penelitian ini bertujuan untuk menguji secara empirik peran pengelolaan kelas dan orientasi tujuan penguasaan terhadap regulasi diri dalam belajar Matematika. Subjek penelitian sebanyak 177 siswa SMA Negeri di Sleman, yang diambil dengan teknik purposive sampling. Instrumen pengukuran yang digunakan adalah skala regulasi diri belajar Matematika, skala pengelolaan kelas, dan skala orientasi tujuan penguasaan. Analisis data dengan menggunakan analisis regresi dua prediktor menunjukkan bahwa pengelolaan kelas dan tujuan penguasaan secara bersama-sama berperan sebesar 68,7\% (R2=0,687, F $(2,177)=191.243, \mathrm{p}<0,01)$. Pengelolaan kelas memprediksi regulasi diri belajar Matematika $(\beta=-0,130, p<0,01)$, begitu pula tujuan penguasaan $(\beta=0,878, p<0,01)$. Hasil penelitian dapat disimpulkan bahwa regulasi diri belajar Matematika dapat ditentukan secara bersama-sama dari peran pengelolaan kelas dan tujuan penguasaan.
\end{abstract}

Kata Kunci: orientasi belajar penguasaan; pengelolaan kelas; regulasi diri; belajar Matematika

\footnotetext{
*Corresponding Author: Asmadi Alsa (e-mail: asmalsa@ugm.ac.id). Program Doktor Ilmu Psikologi Fakultas Psikologi Universitas Persada Indonesia YAl. Jl. Diponegoro No. 74 Jakarta 10340, Indonesia.
} 


\section{Introduction}

Learning activities at the level of secondary school require students to be independent in order to direct their learning behaviours. The competencies needed are independence, responsibility, and problem solving (Bell \& Pape, 2014). A student is considered able to learn when the student controls and directs his/her behaviours to reach goals by self-regulating (Boekaerts \& Cascallar, 2006; Chung, 2000).

Self-regulated learning is the ability to reach a learning goal with active participation in terms of cognition, motivation, and behaviour (Pintrich, 2004). There are four stages of learning based on self-regulation according to Pintrich (2004), namely: 1) thoughts of the future, 2) planning and action, 3) monitoring and control, and 4) reaction and reflection.

Macklem (2015) explains that students who are able to regulate themselves, manage their learning behaviour, have a motivation, involves cognitive role, and show a regular pattern of learning. They are able to control the process of cognition, motivation, behaviour, and environment (Carneiro, Lefrere, Steffens, \& Underwood, 2011). The learners who have self-regulation are identified with their ability to determine their goal, to manage emotions, to do monitoring, to evaluate obstacles, and to make an adjustment with action to be taken, as well as their high motivation (Santrock, 2009).

Self-regulation can be applied in learning Mathematics that is generally considered a difficult subject by students. The difficulty faced by students in learning this subject lies in the ability to understand a concept, principle, and connectivity (Kumalasari, Oktora, \& Putri, 2013). Recently, Nurhayati and Retnowati (2018) conducted a study in order to discover the types of mistakes made by students when solving Mathematics problems among thirty students in Yogyakarta vocational school the results of the study categorized errors into two types: 1$)$ procedural errors, 2) conceptual error. Moreover, Tanjungsari et al., (2012) diagnosed the difficulties of learning Mathematics among students of SMP Negeri 2 Kertanegara Purbalingga school and they found: 1) difficulties in the ability to translate linguistic knowledge into mathematical equations, 2) difficulties in using the mathematical principles, 3) difficulty in using mathematical concepts, and 4) difficulties in algorithmic abilities.

The results of the study done by Tias and Wutsqa (2015) on twelfth-grade high school students of physics class group showed that the difficulty faced by these students was in understanding a concept, fact, procedures, and visualspatial processing. They could not read the mathematic problems well, to analyze answer, to remember the concept or principle supposed to be used, to use procedures or measures in overcoming the problem, and to apply strategies in overcoming the problems. Students regarded Mathematics a difficult subject so that they did not like it, they were not motivated and worried about examination (Susetyo \& Kumara, 2012).

High school students must have been able to regulate themselves, but, in fact, the studies done by Cahyani (2010) and Cahyani and Alsa (2008) in the Indonesian context involving eleventh grader students of a high school as the subjects, discovered that their self-regulated learning was still inadequate. They were not able to manage themselves and time. They were inconsistent, lazy, and less attentive to the teachers' explanation. They studied before examination only. They were unconfident, doubtful, anxious, and indifferent. 
Internal and external factors can contribute to self-regulation in learning activities. The internal factors are, for example, goal orientation (Puspitasari, Purwanto, \& Noviyani, 2013; Yailagh, Birgani, Boostani, \& Hajiyakhchali, 2013). The external factors are, for example, the way teachers teach (Ramos \& Anonuevo, 2011), teachers' teaching methods (Samuelsson, 2008), teachers' interpersonal communication (Erawati, 2016; Rianatha \& Sawitri, 2015), and teachers' teaching quality (Rashid, Abbass, Hussain, Khalid, \& Salfi, 2014). Therefore, this study focused on classroom management and mastery goal orientation.

The concept of self-regulation is rooted in social cognitive theory. According to Bandura (1986), self-regulation can be determined by mutual interaction between individuals, behaviours, and environment. Social environment, for example, teachers, can influence the development of self-regulation in learning. Students perceive teachers' classroom management. The study done by Kareshki (2011) showed that students' perceptions of classroom activities affect their self-regulation in learning. Activities in the classroom involve teachers' practices, whether their teaching is interesting, challenging, and convenient, or vice versa.

Classroom management is the way a teacher optimizes students' involvement, handles students' deviant behaviours, creates a positive classroom climate, facilitates the optimal learning process, and understands students' personal and academic conditions (Jones \& Jones, 2012). It is said to be effective if the disturbing situation is overcome and the classroom becomes conducive for learning activities (Skiba, Ormiston, Martinez, \& Cummings, 2016). Effective classroom management can be accomplished through approaches that are more psychological such as teaching through interactions (Hafen \& Ruzek, 2015). The approach is a connective instruction, which emphasizes personal interaction between the teacher and each student, in which the student is encouraged to participate very much. Students will feel happy and comfortable at school if teachers are able to create good personal relationship during learning activities at the class (Booker \& Lim, 2018; Cheung, Cheung, \& Hue, 2017; Djigic \& Stojiljkovic, 2011). A teacher who can teach well facilitates the students to regulate themselves in learning (Özyildirim et al., 2011; Shahmohammadi, 2014). Classroom management plays a role in developing the dimensions of self-regulated learning, namely motivation, cognitive strategy, and resource management strategy. Viewed from the dimension of motivation, a teacher plays a role in motivating students. A teacher who is able to foster or encourage motivation will make students active in class, increasing the students' effort and diligence, and directing them to be able to regulate themselves (Ramos \& Anonuevo, 2011). During the learning process, a good teacher will give feedback to the students' works. Teacher's ability to give feedback can encourage the students to learn more, especially in completing tasks (Endedijk, Brekelmans, Verloop, Sleegers, \& Vermunt, 2014).

Teacher will activate students' cognitive ability in order that they are able to organize the learning materials they get, to elaborate the materials and relate them to the knowledge they already have, to make an analogy by giving conceptual illustration based on the information that they have understood (Slavin, 2011). Teacher's ability to understand every student's character also contributes to their self-regulation (Peeters, De Backer, Kindekens, Triquet, \& Lombaerts, 2016). A teacher can direct students so that they are not afraid to ask about learning difficulties. A student who is able to manage 
his/her resources is a student who can manage time and learning environment.

A teacher can also support students' effort to be able to master a subject. Schunk et al., (2012) explained that the orientation to mastery means students' effort to understand and improve their knowledge. Students who have mastery goal orientation are able to adjust with the tasks and materials of the subject so that they can easily absorb the knowledge learned (Belenky \& NokesMalach, 2012). Information from the materials will be processed in the information processing system of the sensory register, working memory, and long-term memory. Slavin (2011) explained that the brain's reticular activating system screens information to focus on important materials, then remove the unimportant ones. Information received from the sensory register is transferred to working memory, and then stored in long-term memory. Information also moves to the amygdala that determines reaction towards the existing emotion. Emotion can help direct attention needed in learning. The results of the study done by Kolkman et al. (2013) explain that the brain system that works in doing Mathematics is an executive function. The components of this executive function are working memory, inhibitory control that has the ability to stop response from a task, and switching that is connected to mental set ability and task (Haan, 2014).

Mastery goal orientation affects self-regulation in learning (Ozkal, 2013; Sadi \& Uyar, 2013) and especially in learning Mathematics (Fadlelmula, 2010). It can influence motivation, cognition, and resource management strategy. Mastery goal orientation can direct an individual to get motivated to (Hejazi, Naghsh, Sangari, \& Tarkhan, 2011). When trying to master the materials learned, students can direct themselves to activate cognitive process like thinking critically, planning and monitoring their learning process, and evaluating the results (Yaghoubi, 2013). Students who have mastery goal orientation will make learning strategy and try to find assistance to overcome learning at home (Keachies, 2014). The results of the study done by Gonida, Karabenick, Makara, and Hatzikyriakou, (2014) showed that students who have mastery goal orientation desire to seek assistance and will feel the benefits of it.

Based on the explanation, the hypothesis of this study proposed was that classroom management and mastery goal orientation simultaneously can predict student's self-regulation of Mathematics learning.

\section{Method}

The subjects of this study were as many as 177 high school students, consisting of 87 eleventh graders and 90 twelfth graders of the natural science class. Based on gender, the females were 103 (58.19\%) and male 74 (41.80\%). They were selected using a purposive sampling technique. The criteria were students who were from natural science branch, and their schools being located in a suburban area, applying the curriculum of 2013, and having the A level of accreditation.

The measuring instruments used in this study were self-regulation scale, classroom management scale, and mastery goal orientation scale. The self-regulation scale referred to the one developed by Pintrich et al. (1991), which consists of three dimensions i.e. motivation, cognition, and resource management strategy. It consists of 63 items with a choice of answer from 'Very Often' to 'Very Rarely'. The psychometric property of selfregulation scale has the coefficient $\alpha=0,96$ with the coefficient of variation ranging from 0.304 to 
0.692, and the validity coefficient of Aiken's V ranging from 0.69 t0 0.94 .

The scale of classroom management consists of 53 items, with a choice of answer from Very Suitable (SS) to Very Unsuitable (STS) answers. The scale of class management arranged by the researcher referred to the scale developed by Hafen \& Ruzek (2015) which consists of the dimensions of emotional support, class organization, and instructional support. This scale has $\alpha=0.97$, with the coefficient of variation ranging from 0.401 to 0.703 , and the validity coefficient of Aiken's V ranging from 0.81 to 0.94 .

The mastery goal orientation scale consists of 48 items, with the same answer choices as the classroom management scale. This scale arranged by the researchers referred to the scale by Schunk et al. (2012). The aspects of mastery goal orientation consist of the views on 1) success, 2) values, 3) effort reasons, 4) evaluation criteria, 5) errors, 6) patterns of the formation of perception of causes, 7) satisfaction with success, 8) use of strategies, and 9) behaviour towards the task. The Cronbach's Alpha coefficient of this instrument is $\alpha=0.96$ with the coefficient of variation ranging from 0.400 to 0.663 , and the validity coefficient of Aiken's V ranging from 0.85 to 0.94 .

\section{Results}

The research data were analyzed using multiple regression to determine the role of classroom management and mastery goal orientation towards self-regulation of Mathematics learning. Normality and multicollinearity assumption tests were performed first before conducting data analysis. The results of the normality test with Kolmogorov-Smirnov ( $\mathrm{Z}_{\mathrm{KS}}$ ) noted that the data were normally distributed. $Z_{\mathrm{KS}}$ value on the selfregulation variable was 0.706 ( $p>0.05$ ), on the classroom management variable was 0.720 ( $p>$ 0.05 ) and on the goal orientation variable was 1.329 ( $p>0.05$ ). Multicollinearity test results were shown by the value of tolerance $=0.806$ and VIF $=$ 1.241.

Based on the results of the multiple regression analysis it was found that classroom management and mastery goal played a significant role of $68.7 \%$ (R2 = 0.687, $\mathrm{F}(2,177)=$ $191,243, \mathrm{p}<0.01)$. Based on these results it could be concluded that the research hypothesis was accepted, meaning that classroom management and mastery goal orientation together can predict self-regulation of Mathematics learning. Together class management and mastery goal orientation gave $68.7 \%$ of the contribution. Classroom management played a role in predicting the selfregulation of Mathematics learning $(\beta=-0.130, p$ $<.01)$, as well as mastery goal orientation $(\beta=$ $0.878, \mathrm{p}<0.01$ ). The contribution of classroom management to self-regulation of Mathematics learning was $3.3 \%$, while that of mastery goal orientation was $72 \%$.

The results of the regression analysis of Mathematics-learning self-regulation with predictors of classroom management and mastery goal orientation are shown in Table 1. Unstandardized coefficients (classroom management) and mastery goal orientation were used to compile a regression line equation to predict scores of self-regulation of Mathematics learning.

The equation shows that when the classroom management was constant, the goal orientation score increased by one point, and it increased selfregulation of Mathematics learning by 1,125 points. Conversely, when the mastery goal orientation was constant, the score of the classroom management increased by one point, and then the score of the self-regulation of Mathematics learning decreased by 0.137 points. 
Tabel 1.

Results of regression analysis on self-regulation of Mathematics learning with the predictors of classroom management and mastery goal orientation

\begin{tabular}{lccccc}
\hline Variable & \multicolumn{2}{c}{$\begin{array}{c}\text { Unstandardized } \\
\text { Coefficients }\end{array}$} & $\begin{array}{c}\text { Standardized } \\
\text { Coefficients }\end{array}$ & T & $\begin{array}{c}\text { Sig. } \\
\text { Bero- } \\
\text { order }\end{array}$ \\
\hline (Constant) & B & Std. Error & Beta & & \\
Classroom management & $-0,137$ & 0,050 & $-0,130$ & $-2,756$ & 0,006 \\
Mastery Goal Orientation & 1,125 & 0,061 & 0,878 & 18,594 & 0.000 \\
\hline \\
Equation of the regression line:
\end{tabular}

\section{Discussion}

The results showed that classroom management and mastery goal orientation acted as predictors of self-regulation of Mathematics learning. The results of regression analysis showed that classroom management and mastery goal orientation played an effective contribution of $68.7 \%$, meaning that jointly classroom management and mastery goal orientation can be said to act as predictors of self-regulation of Mathematics learning.

Self-regulation has a role in directing behaviour and is influenced by the role of the reciprocal relationship between internal factors and external factors. Students are internal factors, while teachers are external factors that play a role in the self-regulation of Mathematics learning. Teachers who are able to teach well can influence students' self-regulation in learning (Özyildirim et al., 2011). The research done by Sakiz et al. (2012) explains that teachers can create a pleasant academic atmosphere, provide self-confidence, and encourage academic effort while teaching Mathematics so that students are more motivated. If a teacher is able to create a pleasant atmosphere, students will like the teacher in delivering the subject and it will be easy for them to understand. Instead, if a teacher shows unpleasant behaviour, students will not like the teacher and the subject being taught. If a subject like Mathematics is taught by a teacher in a less pleasant way, conventionally instructing students to memorize formulas and solve problems only, students may hate the subject. Mathematics can be taught in a fun way, such as using props, playing games, making it into songs or poetry (Ramdhani, 2012).

Class management is a determinant that plays a role in learning strategies, especially selfregulation. A teacher can facilitate students in developing their self-regulation by making them more active while learning in class. Rashid et al. (2014) explained that teachers can activate students in learning through classroom management, such as building social relationships with students, involving students in completing assignments, building cooperation with other teachers and being fair in giving treatment. More attention from the teacher can make students more actively involved in learning in the class (Nie \& Lau, 2009).

Based on the results of multiple regression analysis, it was discovered that classroom management had a negative contribution of $3.3 \%$ 
to Mathematics-learning self-regulation. This means that if the value of the mastery goal orientation is constant, the addition of one point in the value of classroom management will reduce the self-regulation of Mathematics learning. This shows that the contribution of classroom management can reduce self-regulation when it is done simultaneously with the mastery goal orientation. This result seems illogical and one possible explanation for the negative impact of classroom management on self-regulation of Mathematics learning that; possibly students perceived class management as a face of rigid practices done by their teachers and they considered classroom management as an aspect of forcing authority (Pamuk, 2014) especially under the condition of under-estimation of teachers these days. Teachers need to pay attention to student's mastery of materials in learning Mathematics. The progressions in mastering subject's materials can be different in every student, so teachers need to pay attention to the attribution of effort made by students. If the teacher pays attention to students' efforts, then students who have below-average abilities will feel valued because what is visible are not only the results but also the process. Slavin (2011) explains that the achievement of success and failure is determined by ability, effort, task difficulty, and luck. Ability is considered a relatively stable state, whereas luck is unstable and cannot be controlled. Students try to explain success and failure in learning in different ways. This is in line with the results of the research by Susetyo \& Kumara (2012) on eleventh-grade high school students of physics class which explains that students who use attributions of failure due to lack of effort show a higher level of selfregulation than students with attributions of difficulty, tasks and fate.

Not all teachers can encourage students to be more interactive in learning activities. Boyd \& Ash (2018) explained that it is difficult to change the things that teachers are accustomed to in teaching. Further, it was explained that teachers need to have confidence in understanding students' problems in learning Mathematics. This means that a teacher's personality contributes to determining classroom management. Jones and Jones (2012) explained that some teachers can also choose not to be too personal, even though students want to be close to them. In dealing with students, every teacher can have different personal competence in classroom management, so that it can have an impact on student's learning behaviour.

Teachers need to have professional teaching competencies so that their classroom management can be more optimal. The competencies as mentioned by Ramdhani (2012) are; 1) pedagogical competence, which is related to the ability to recognize student's character, to master learning theory, and to apply learning principles according to the stages of student development; 2) personality competence, which is related to honesty, morals noble, exemplary, stability, maturity, intelligence and author; 3) social competence, which is related to the ability to interact with the environment; and 4) professional competence, which is related to the ability to master the contents and structures of teaching materials. The improvement of each competency can be done in different ways. Pedagogical competence can be achieved if a teacher is able to understand students' characteristics according to their stage of development. Personality competence can be optimized if a teacher can recognize and develops positive emotions. A teacher can increase knowledge for improving professional competence. Social competence requires good interaction with students, especially in giving attention.

Teachers' teaching competencies can support the development of student's self-regulation. Teachers who have social competence can more 
easily activate the learning process that involves collaboration. The approach that can be done is by socially shared regulated learning, namely selfregulation in learning through collaboration that involves interaction with other students or when becoming part of other group members (Grau et al., 2018). Regarding personal competence, teachers can provide examples of behaviours that lead students to self-regulate. Teacher's behaviour can be used as a model by students, so they will imitate it. Bandura (1986) explained that learning can be done by modelling, which consists of the process of paying attention, retention, production, and motivation. Modelling functions are to facilitate response and direct action.

Students' self-regulation is not only determined by the role of their teachers, but the results of this study also proved that mastery goal orientation has a greater role in the selfregulation of Mathematics learning than classroom management. The mastery goal orientation is related to learning strategies that can be applied by students (Michou, Mouratidis, Lens, \& Vansteenkiste, 2013).

Students who have a goal orientation are able to show better performance in learning. Bandura (1986) explained that performance can be assessed by individuals based on their standards. The stage after giving an assessment is to give a reaction, which can be positive, negative or not to react. A positive reaction can be analogous that students give a positive assessment of their ability in mastering materials. Schunk et al, (2012) explained that if students have a mastery goal orientation, they will care about learning, mastery of tasks and competence enhancement. The other features are the perseverance, and the ability to overcome failures and difficult tasks (Ormrod, 2009). By having a good mastery goal orientation, students are more likely to see a strong correlation between effort and results. This is in line with research from Chatzisarantis et al., (2016) which showed that students who have mastery goal orientation are more adaptive in conducting self-regulation in learning.

When learning Mathematics, students will show a better ability to think and try if they have a mastery goal orientation (Bostwick, Martin, Collie, \& Durksen, 2019). In line with this study, the research by Mouratidis et al., (2018) found that students in secondary schools who have a goal mastery orientation in Mathematics feel more challenged in mastering the material.

Mastery of Mathematics in high school students requires them to have the ability to explain and analyze situations with mathematical terms (Santrock, 2011). The process of analyzing mathematical problems involves the activation of cognitive processes in the brain system. The control that plays a role is the executive function that organizes tasks and directs behaviour (Banich \& Compton, 2011). The executive function plays a role in the ability to solve mathematical problems (Verdine, Irwin, Golinkoff, \& Hirsh-Pasek, 2014). The executive function in the learning process consists of shifting, which is related to the task and mental set settings, updating, which is related to processing information in working memory, and inhibition, which is related to the process of controlling the response when completing a task (Barenberg, Berse, \& Dutke, 2011).

\section{Conclusion}

Based on the results of this study, it could be concluded that classroom management and mastery goal orientation at the same time can predict student's self-regulation of Mathematics learning. It means that self-regulation can be determined simultaneously with classroom management and mastery goal orientation of the students. 
The findings of this study can contribute to the development of learning strategies, especially students' self-regulation. For any following study, it is recommended to study self-regulation in learning other subjects with different participants.]

\section{References}

Bandura, A. (1986). Social foundations of thought and action: A social cognitive theory. In Social foundations of thought and action: A social cognitive theory. New Jersey: Prentice Hall, Inc., Englewood Cliffs.

Banich, M. T., \& Compton, R. J. (2011). Cognitive neuroscience (3rd ed.). Belmont: Wadsworth, Cengage Learning.

Barenberg, J., Berse, T., \& Dutke, S. (2011). Executive functions in learning processes: Do they benefit from physical activity? Educational Research Review, 6(3), 208-222. https://doi.org/ 10.1016/j.edurev.2011.04.002

Belenky, D. M., \& Nokes-Malach, T. J. (2012). Motivation and transfer: The role of mastery-approach goals in preparation for future learning. Journal of the Learning Sciences, 21(3), 399-432. https://doi.org/10.1080/10508406.2011.651232

Bell, C. V., \& Pape, S. J. (2014). Scaffolding the development of self-regulated learning in Mathematics classrooms. Middle School Journal, 45(4), 23-32. https://doi.org/10.1080/00940771. 2014.11461893

Boekaerts, M., \& Cascallar, E. (2006). How far have we moved toward the integration of theory and practice in self-regulation? Educational Psychology Review, 18(3), 199-210. https:// doi.org/10.1007/s10648-006-9013-4

Booker, K. C., \& Lim, J. H. (2018). Belongingness and pedagogy: Engaging African American girls in middle school Mathematics. Youth and Society, 50(8), 1037-1055. https://doi.org/ 10.1177/0044118X16652757

Bostwick, K. C. P., Martin, A. J., Collie, R. J., \& Durksen, T. L. (2019). Growth orientation predicts gains in middle and high school students' Mathematics outcomes over time. Contemporary Educational Psychology, 58, 213-227. https://doi.org/10.1016/j.cedpsych.2019.03.010

Boyd, P., \& Ash, A. (2018). Mastery Mathematics: Changing teacher beliefs around in-class grouping and mindset. Teaching and Teacher Education, 75, 214-223. https://doi.org/10.1016/ j.tate.2018.06.016

Cahyani, B. H. (2010). Pelatihan regulasi metakognisi untuk meningkatkan kebiasaan belajar. Yogyakarta: Universitas Sarjanawiyata Tamansiswa.

Cahyani, B. H., \& Alsa, A. (2008). Efektivitas pelatihan regulasi metakognisi untuk meningkatkan kemampuan memecahkan problem Matematika. (Unpublished thesis). Universitas Gadjah Mada.

Carneiro, R., Lefrere, P., Steffens, K., \& Underwood, J. (2011). Self-regulated learning in technologyenhanced learning environments a European perspective (5th ed.). Rotterdam: Sense Publisher.

Chatzisarantis, N. L. D., Nilay Ada, E., Bing, Q., Papaioannou, A., Prpa, N., \& Hagger, M. S. (2016). Clarifying the link between mastery goals and social comparisons in classroom settings. Contemporary Educational Psychology, 46, 61-72. https://doi.org/10.1016/j.cedpsych.2016.04.009 
Cheung, C., Cheung, H. Y., \& Hue, M. (2017). Educational contributions to students' belongingness to the society, neighbourhood, school and family. International Journal of Adolescence and Youth, 22(2), 226-237. https://doi.org/10.1080/02673843.2016.1157827

Chung, M.-K. (2000). The development of self-regulated learning. Asia Pacific Education Review, 1(1), 55-66. https://doi.org/10.1007/bf03026146

Djigic, G., \& Stojiljkovic, S. (2011). Classroom management styles, classroom climate and school achievement. Procedia - Social and Behavioral Sciences, 29, 819-828. https://doi.org/ 10.1016/j.sbspro.2011.11.310

Endedijk, M. D., Brekelmans, M., Verloop, N., Sleegers, P. J. C., \& Vermunt, J. D. (2014). Individual differences in student teachers' self-regulated learning: An examination of regulation configurations in relation to conceptions of learning to teach. Learning and Individual Differences, 30, 155-162.https://doi.org/10.1016/j.lindif.2013.12.005

Erawati, M. (2016). Pembentukan rapport di kelas: Analisis psikologi. Psikohumaniora: Jurnal Penelitian Psikologi, 1(1), 75. https://doi.org/10.21580/pjpp.v1i1.1001

Fadlelmula, F. K. (2010). Educational motivation and students' achievement goal orientations. Procedia Social and Behavioral Sciences, 2(2), 859-863. https://doi.org/10.1016/j.sbspro.2010.03.116

Gonida, E. N., Karabenick, S. A., Makara, K. A., \& Hatzikyriakou, G. A. (2014). Perceived parent goals and student goal orientations as predictors of seeking or not seeking help: Does age matter? Learning and Instruction, 33, 120-130. https://doi.org/10.1016/j.learninstruc.2014.04.007

Grau, V., Lorca, A., Araya, C., Urrutia, S., Ríos, D., Montagna, P., \& Ibaceta, M. (2018). Socially shared regulation of learning and quality of talk: Age differences in collaborative group work in classroom contexts. New Directions for Child and Adolescent Development, 2018(162), 11-39. https://doi.org/10.1002/cad.20261

Haan, de M. (2014). Attention and executive control. In Educational neuroscience (1st ed., p. 326). West Sussex: Willey Blackwel.

Hafen, C. A., \& Ruzek, E. A. (2015). Classroom Level in Educational Effectiveness Research. In International Encyclopedia of the Social \& Behavioral Sciences (pp. 833-838). Elsevier. https://doi.org/10.1016/B978-0-08-097086-8.92127-5

Hejazi, E., Naghsh, Z., Sangari, A. A., \& Tarkhan, R. A. (2011). Prediction of academic performance: The role of perception of the class structure, motivation and cognitive variables. Procedia - Social and Behavioral Sciences, 15, 2063-2067. https://doi.org/10.1016/j.sbspro.2011.04.054

Jones, V., \& Jones, L. (2012). Manajemen kelas komprehensif. (I. Irawati, Trans.) (9th ed.). Jakarta: Kencana Prenada Media Group.

Kareshki, H. (2011). Relations among perceptions of classroom activities and self-regulating learning. Procedia - Social and Behavioral Sciences, 12, 409-413. https://doi.org/10.1016/ j.sbspro.2011.02.050

Keachies, M. (2014). Teaching tips strategies, research and Theory for College and University Teachers (14th ed.). Boston: Wadsworth Cengage Learning.

Kolkman, M. E., Hoijtink, H. J. A., Kroesbergen, E. H., \& Leseman, P. P. M. (2013). The role of executive functions in numerical magnitude skills. Learning and Individual Differences, 24, 145-151. https://doi.org/10.1016/j.lindif.2013.01.004

Kumalasari, A., Oktora, R., \& Putri, P. E. (2013). Kesulitan belajar Matematika siswa ditinjau dari segi kemampuan koneksi Matematika. In Prosiding Seminar Nasional Matematika dan Pendidikan Matematika (pp. 978-979). Yogyakarta: Jurusan Pendidikan Matematika FMIPA UNY. 
Macklem, G. L. (2015). Boredom in the classroom addressing student motivation, self-regulation, and engagement in learning. New York: Springer.

Michou, A., Mouratidis, A., Lens, W., \& Vansteenkiste, M. (2013). Personal and contextual antecedents of achievement goals: Their direct and indirect relations to students' learning strategies. Learning and Individual Differences, 23, 187-194. https://doi.org/10.1016/j.lindif.2012.09.005

Mouratidis, A., Michou, A., Demircioğlu, A. N., \& Sayil, M. (2018). Different goals, different pathways to success: Performance-approach goals as direct and mastery-approach goals as indirect predictors of grades in Mathematics. Learning and Individual Differences, 61, 127-135. https://doi.org/10.1016/j.lindif.2017.11.017

Nie, Y., \& Lau, S. (2009). Complementary roles of care and behavioral control in classroom management: The self-determination theory perspective. Contemporary Educational Psychology, 34(3), 185194. https://doi.org/10.1016/j.cedpsych.2009.03.001

Nurhayati, R., \& Retnowati, E. (2018). An Analysis of Errors in Solving Limits of Algebraic Function. In Journal of Physics: Conference Series (Vol. 1320, p. 12034). \{IOP\} Publishing. https://doi.org/ 10.1088/1742-6596/1320/1/012034

Ormrod, J. E. (2009). Psikologi pendidikan: Membantu siswa tumbuh dan berkembang. (A. Kumara, Trans.) (6th ed.). Jakarta: Erlangga.

Ozkal, N. (2013). The relationship between achievement goal orientations and self regulated learning strategies of secondary school students in social studies courses. International Journal of Academic Research, 5(3), 389-396. https://doi.org/10.7813/2075-4124.2013/5-3/B.59

Özyildirim, F., Alkas, C., \& Ozdemir, E. Y. (2011). The factors that affect the preservice Mathematics teachers ' self regulation strategies. Procedia - Social and Behavioral Sciences, 15, 3543-3549. https://doi.org/10.1016/j.sbspro.2011.04.332

Pamuk, S. (2014). Multilevel analysis of students science achievement in relation to constructivist learning environment perceptions, epistemological beliefs, self-regulation and science teachers characteristics. Middle East Technical University, Ankara, Turkey.

Peeters, J., De Backer, F., Kindekens, A., Triquet, K., \& Lombaerts, K. (2016). Teacher differences in promoting students' self-regulated learning: Exploring the role of student characteristics. Learning and Individual Differences, 52, 88-96. https://doi.org/10.1016/j.lindif.2016.10.014

Pintrich, P. R. (2004). A conceptual framework for assessing motivation and self-regulated learning in college students. Educational Psychology Review, 16(4), 385-407. https://doi.org/ 10.1007/s10648-004-0006-X

Pintrich, P. R., Smith, D. A. F., Garcia, T., \& McKeachie, W. J. (1991). A manual for the use of the Motivated Strategies for Learning Questionnaire (MSLQ. Washington, DC.

Puspitasari, A., Purwanto, E., \& Noviyani, D. I. (2013). Self-regulated learning viewed from the goal orientation. Educational Psychology Journal, 2(1), 1-6.

Ramdhani, N. (2012). Menjadi guru inspiratif. Jakarta: Titian Foundation.

Ramos, R. C., \& Anonuevo, M. J. T. (2011). Engagement-promoting aspects of teacher's instructional style and academic self-regulated learning. The International Journal of Research and Review, 7(2), 51-62.

Rashid, K., Abbass, A., Hussain, A., Khalid, N., \& Salfi, N. A. (2014). Perceptions of students about classroom management as a contributing factor towards learning at secondary school. Journal of Education and Human Development, 3(2), 713-728. 
Rianatha, L., \& Sawitri, D. R. (2015). Hubungan antara komunikasi interpersonal guru-siswa dengan selfregulated learning pada siswa SMAN 9 Semarang. Jurnal Empati, 4(2), 209-213.

Sadi, O., \& Uyar, M. (2013). The relationship between self-efficacy, self-regulated learning strategies and achievement: A path model. Journal of Baltic Science Education, 12(1), 21-33.

Sakiz, G., Pape, S. J., \& Hoy, A. W. (2012). Does perceived teacher affective support matter for middle school students in Mathematics classrooms? Journal of School Psychology, 50(2), 235-255. https://doi.org/10.1016/j.jsp.2011.10.005

Samuelsson, J. (2008). The impact of different teaching methods on students' arithmetic and self-regulated learning skills. Educational Psychology in Practice, 24(3), 237-250. https://doi.org/10.1080/02667360802256790

Santrock, J. W. (2009). Psikologi pendidikan, buku 1. (D. Angelica, Trans.) (2nd ed.). Jakarta: Salemba Humanika.

Santrock, J. W. (2011). Perkembangan masa hidup. (B. Widyasinta, Trans.) (13th ed.). Jakarta: Erlangga.

Schunk, D. H., Pintrich, P. R., \& Meece, J. L. (2012). Motivasi dalam pendidikan: Teori, penelitian dan aplikasi. (E. Tjo, Trans.) (3rd ed.). Jakarta: Indeks.

Shahmohammadi, N. (2014). Review on the impact of teachers' behaviour on students' self- regulation. Procedia - Social and Behavioral Sciences, 114, 130-135. https://doi.org/10.1016/ j.sbspro.2013.12.672

Skiba, R., Ormiston, H., Martinez, S., \& Cummings, J. (2016). Teaching the social curriculum: Classroom management as behavioral instruction. Theory Into Practice, 55(2), 120-128. https://doi.org/10.1080/00405841.2016.1148990

Slavin, R. E. (2011). Psikologi pendidikan. (M. Samosir, Trans.) (2nd ed.). Jakarta: Indeks.

Susetyo, Y. ., \& Kumara, A. (2012). Orientasi tujuan, atribusi penyebab, dan belajar berdasar regulasi diri. Jurnal Psikologi, 39(1), 95-111. https://doi.org/10.22146/JPSI.6969

Tanjungsari, R. D., Soedjoko, E., \& Mashuri. (2012). Diagnosis kesulitan belajar Matematika SMP pada materi persamaan garis lurus. Unnes Journal of Mathematics Education., 1(1), 53-57. https://doi.org/10.15294/ujme.v1i1.261

Tias, A. A. W., \& Wutsqa, D. U. (2015). Analisis kesulitan siswa sma dalam pemecahan masalah Matematika kelas XII IPA di kota Yogyakarta. Jurnal Riset Pendidikan Matematika, 2(1), 28. https://doi.org/10.21831/jrpm.v2i1.7148

Verdine, B. N., Irwin, C. M., Golinkoff, R. M., \& Hirsh-Pasek, K. (2014). Contributions of executive function and spatial skills to preschool Mathematics achievement. Journal of Experimental Child Psychology, 126, 37-51.https://doi.org/10.1016/j.jecp.2014.02.012

Yaghoubi, A. (2013). Critical thinking and goal orientation among English language students. Procedia Social and Behavioral Sciences, 93, 77-82. https://doi.org/10.1016/j.sbspro.2013.09.155

Yailagh, M. S., Birgani, S. A., Boostani, F., \& Hajiyakhchali, A. (2013). The relationship of self-efficacy and achievement goals with metacognition in female high school students in Iran. Procedia - Social and Behavioral Sciences, 84, 117-119. https://doi.org/10.1016/j.sbspro.2013.06.520 